\title{
Implicated Literacies: Life Begetting Life in Linguistic Education
}

\section{Letramentos Implicados: vida gerando vida na educação linguística}

\author{
Simone Batista da Silva* \\ *Universidade Federal Rural do Rio de Janeiro (UFRRJ), Seropédica, Rio de Janeiro / \\ Brasil \\ simonebatista@uol.com.br
}

https://orcid.org/0000-0002-5781-6006

\begin{abstract}
We are almost 8 billion people to live, eat and survive on the only inhabitable planet, yet few of us care for environmental issues. Our relationship with the Nature, in general, has been one of exploitation and spoliation, following the anthropocentric modern narrative that prioritizes an egocentric mindset. The outcomes are deprivation, scarcity, depletion of natural organisms, destruction of the space as a whole. Anchored in decolonial and transdisciplinary studies, this text ponders on the consequences of the Eurocentric narratives, claims the need of collectively building a different narrative, and advocates in favor of implicated literacies, a pedagogy for language teaching that understands that "life on Earth implicates life", and encourages the improvement of environmental and social relations in a broader conception of sustainability.
\end{abstract}

KEYWORDS: sustainability; linguistic education; implicated literacies.

RESUMO: Somos quase 8 bilhões de pessoas para viver, comer e sobreviver no único planeta habitável, mas poucos de nós se preocupam com questões ambientais. Nossa relação com a Natureza, em geral, tem sido de exploração e espoliação, seguindo a narrativa antropocêntrica moderna, que prioriza uma mentalidade egocêntrica. Os resultados têm sido privação, escassez, esgotamento dos organismos naturais, destruição do espaço como um todo. Ancorado nos estudos decoloniais e transdisciplinares, este texto pondera sobre as consequências das narrativas eurocêntricas, afirma a necessidade de construir coletivamente uma narrativa diferente, e advoga em favor de letramentos implicados, uma pedagogia para o ensino de línguas que entende que "a vida na Terra implica vida", e incentiva a melhorar as relações ambientais e sociais em uma concepção ampliada de sustentabilidade.

PALAVRAS-CHAVE: sustentabilidade; educação lingüística; letramentos implicados. 


\section{Introduction}

Some months ago, I looked for practical roles of animals and plants for the operation of the world. In a quick search at the US Geological Survey site $^{1}$, I found out that bats, for example, are important creatures for forest ecosystems, and saves US Agriculture billions of dollars in pest control. The same site explains that bees, birds, and butterflies are very important creatures for the ecosystem once they are pollinators, and wherever they go they potentialize life all around them (idem). Recent forest engineering studies (WOHLLEBEN, 2017) point out that some trees in the Northern hemisphere produce a surplus of flowers and fruits they would need for their own reproduction, exactly at the seasons when wild boar mommies need a huge amount of fat to get warm and protected throughout the winter, in an explicit act of collaboration between species. These are just a few samples of living creatures which, just by occupying spaces and maintaining their lives, cooperate for other ones to keep living.

Those examples made me think of Krenak's assertion that "Life here in an earthly sense is an implicated life, a life that implicates producing life, it's life creating life"2 3 (KRENAK, 2020, 27'17'). At that time, a question came to my mind and I wondered whether the human species would also carry an important role for the environment and the ecosystem, and to what extent our existence on Earth as social beings, in fact, implicates life.

My preoccupation is still here with me as the newspapers show that, in my country, we have reached the highest index of firearms record since counting began, in 2009: 180 thousand new fire guns were registered in Brazil in 2020. That means an increase of $91 \%$ in relation to 2019 , which had, itself, presented, an $84 \%$ increase compared to the previous year, $2018 .^{4}$ Those indexes don't seem to be life implicating life. On the contrary, they signal we are going straight the opposite way.

\footnotetext{
${ }^{1}$ Available at: https://www.usgs.gov/. Accessed on: Oct. 8, 2020.

${ }^{2}$ In the original: "A vida aqui no sentido aqui da terra é uma vida implicada, uma vida que implica produzir vida, é a vida criando vida" (tradução minha).

${ }^{3}$ All translations used in this text are my responsibility.

${ }^{4}$ Available at: https://oglobo.globo.com/brasil/brasil-tem-recorde-de-180-mil-novasarmas-de-fogo-registradas-na-pf-em-2020-24830643. Accessed on: Jan. 8, 2021.
} 
We are almost 8 billion people living together in the same space: the surface of the planet. There is no other place to go, as far as we know. However, as a species, our relationship with the Earth has been, for centuries, one of exploitation and spoliation, which indicates that, as living creatures, we have been acting completely different from all the others. Our common space is inhabited by several species, yet our species is the only one that destroys.

The Eurocentric narratives we were told, concerning who we are and should be within this space we occupy, consider us as the owners and masters of the Earth. So, if we are inscribed by the narratives we tell and are told, as Mattos (2010) argues, it is urgent to critically examine those narratives and collectively build a new one. I wish to defend the relevance of reviewing old narratives that claim the Earth to be just a space for us to exploit, and propose a narrative that considers the Earth as a discursive space, continuously under a multispecies collective construction; a narrative that assumes rivers, mountains, seas, animals and plants not as resources to be exploited but as natural entities and partners in sharing and exchanging goods; and that frames the Earth as a giant living organism and life provider. It is an invitation to focus on what our species has been doing to, on, with, and for the space we live in: the planet Earth.

Therefore, in this text I chose to consider the consequences of the Eurocentric narratives we have been told concerning the space we live in, to reassess our relationship with our fellows and with the Earth, and to propose that these issues should be present in our critical linguistic education curricula. So, I stress the urgency of acknowledging that we have egocentric mindsets that should be replaced by ecocentric mindsets, so that we get rid of the phenomenal dissociation bias under which we make meanings in modern societies, in order to improve environmental and social relations in a broader conception of sustainability. Thus, I suggest an approach for linguistic education that I call implicated literacies.

\section{The space we live in}

I want to start by arguing that the space we occupy is not something static and stated, but, instead, it is constantly built with, by and through our discourses and social interactions within this very space. Based on Bourdieu's (2015) understanding that the relationships established among interlocutors 
define the whole society, I infer that roles played, power relations, manifold issues and concerns, together, define the space as either a healthy or a sick one. That is why, in this text, I wish to conceive space as including earthly environment, human and non-human lives, technologies, geographical elements, historical trajectories and the relationships established.

There is only one place in the cosmos where we can live in; only one suitable space for life, so far: The Earth. Despite that, Carl Sagan denounced many years ago that "we are spoiling our planet and becoming a danger to ourselves [...] We lack a consensus on our place in the Universe" (1996, p. 32). ${ }^{5}$ For the latest centuries, the Earth hasn't been considered our home but, instead, a territory to exploit and from which to extract richness to be accumulated. Rivers, mountains, fauna and flora are considered natural resources, not natural companions for a lifetime. As Boff regrets, "the latest centuries were built with their backs to Nature or in aggression against it, when we should feel that we are links in an immense chain of beings and lives"6 (BOFF, 2017, p. 98). The capitalist model of development needs to devastate life on Earth on behalf of accumulation of resources and power for just a few, or, as Comparato (2006, p. 433) summarizes, "capitalist globalization irretrievably disintegrates humanity". 7 That makes clear that, sometimes, what is meant to be development and progress is not always hand in hand with human evolution. On the contrary, it devotes us all to a myopic way of life, that can't see a little further and ignores the interconnection between the species to build the living spaces on this planet.

Anchored on intensive and longitudinal research we can assure today that climate change is mostly anthropogenic, in direct consequence of capitalism, individualism and overconsumption (BOFF, 2017; FOER, 2020; GLEISER, 2014, 2020; OLDSTONE, 1998; WOHLLBEN, 2017; WOODWARD, 2012). Comparato (2006) even asserts that the human interference on the planet is, maybe, the main ethical problem in contemporary days. Our overconsumption and wasteful Western way of

\footnotetext{
${ }^{5}$ In the original: "estamos estragando o nosso planeta e nos tornando um perigo para nós mesmos [...] Falta-nos um consenso sobre nosso lugar no Universo."

${ }^{6}$ In the original: "Os últimos séculos foram construídos de costas para a Natureza ou em agressão contra ela, quando deveríamos sentir que somos elos em uma imensa cadeia de seres e vidas."

${ }^{7}$ In the original: "a globalização capitalista desintegra irremissivelmente a humanidade."
} 
life generates deprivation, social injustice, scarcity, depletion of natural organisms, the looming danger of climate change, a destruction of the space as a whole. Also, it produces poverty so that few ones can pile up, possess and enjoy material goods while many don't have access - in a distinction based on power, wealth and accumulation.

Sousa Santos (2019), an exponent intellectual of decolonial studies, developed the concept of abyssal line, an imaginary line that once separated colonizers and colonized, and by which epistemologies, social groups, ethnic groups, and non-human living creatures are still being oppressed, erased and excluded. The sociologist affirms that the colonial orientations still cross our identities, intertwining our individual and collective discursive practices. Thereupon, trained by the Northern epistemologies, we experience life with abyssal vision and hearing and with an extractivist mindset. These abyssal senses define that "what cannot be seen or heard is not considered relevant"

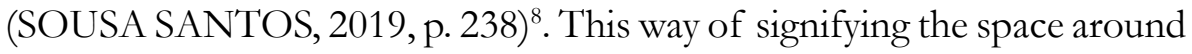
us drives us to a certain selective blindness and deafness that ignore and despise not only the human beings on the other side of the abyssal lines, but also the other living creatures on Earth. And that reduces our possibilities of interactions, constructions, relations and actions besides creating a very restricted reality. Furthermore, it prevents us from recognizing the personhood and subjectivity of the innumerable other living beings that inhabit this earth with us (VIVEIROS DE CASTRO, 2018). It is time to decolonize our senses and try out new forms of experiencing our trajectory as human beings.

The transdisciplinary paradigm of science and education, in the same way, advocates that Nature may be studied by science, but it cannot be analyzed apart from its interaction with humans and their interference. Some indigenous communities in South America corroborate this paradigm as they do not even have different words for "nature", "society" and "culture", once they understand these are inseparable dimensions of the same phenomenon and it would be nonsense to think of each aspect separately (VIVEIROS DE CASTRO, 2018; SCARANO, 2019). As Nicolescu (1999, p. 75) poetically realizes, "[nature] is not a book to be read, but to be

${ }^{8}$ In the original: “o que não pode ser visto ou ouvido não é considerado relevante." 
written". ${ }^{9}$ Yet, the current Western narrative is that humans and nature are different entities and it befits one to exploit the other. The transdisciplinary paradigm recognizes Nature as a living organism, not just a space to occupy: "Nature alive is the matrix of human selfbirth"10 (NICOLESCU, 1999, p. 75). In this perspective, deforestation means mutilation of a living organism (KRENAK, 2020), but we hardly pay attention to that: the anthropocentric overindustrialized way of living presupposes humans separated from and placed above all other living creatures.

Although the modern concept of individualism has disconnected us all from other humans and also from other living creatures, the global document for sustainability - the Earth Charter - with its sixteen principles, goes in a completely opposite direction, and claims that "it is imperative that we, the peoples of Earth, declare our responsibility to one another, to the greater community of life, and to future generations" (UNESCO). ${ }^{11}$ The Earth Charter invites us all to take responsibility with our terrestrial journey human and non-human fellows, and consider the Earth as our inevitable space for interaction, our common home. It encourages us to invest in a responsible, sober, supportive consumption, guided by caring for the Earth and for the other inhabitants, so that we replace the old anthropocentric society for an ecocentric society.

James Lovelock and Lynn Margulis, according to Boff (2017), Scarano (2019) and Foer (2020), once proposed the hypothesis, now scientifically accepted as a theory, that the Earth is Gaia - a giant living organism that provides all we have, happen to be, and where we are all inevitably linked to. In James Lovelock's words,

There is nothing unusual in the idea of life on Earth interacting with the air, sea and rocks, but it took a view from outside to glimpse the possibility that this combination might consist of a single giant living system and one with the capacity to keep the Earth always at a state most favorable for the life upon it. ${ }^{12}$

\footnotetext{
${ }^{9}$ In the original: "[a natureza] não é um livro para ser lido, mas pra ser escrito."

${ }^{10}$ In the original: "A natureza viva é a matriz do autonascimento do homem."

${ }^{11}$ Available at: https:/ / earthcharter.org/read-the-earth-charter/. Accessed on: Jan. 8, 2021.

${ }^{12}$ Available at: http://ecolo.org/lovelock/what_is_Gaia.html. Accessed on:Jan. 13, 2021.
} 
Although the scientific methods to understand and signify the world project clear distinctions between matter and spirit, natural and social, object and subject, male and female, mind and body, material and spiritual, object and subject, contemporary studies in Biology and Anthropology (VIVEIROS DE CASTRO, 2018; WOHLLEBEN, 2017) invite us to try another way of existing in space: one that tries to eliminate dichotomies and blur the frontiers, that acknowledges that subjects are also objects and viceversa. This perspective brings together other human and non-human beings and their technologies, so that diversity, sustainability and plurality become the pattern of life on Earth. It is suggested that we rescue our sense of being part of the whole to build an anti-oppression and difference-accepting mindset society both in relation to other humans and to non-human living creatures. A change in society is demanded: we ought to switch from an egocentric mindset to an ecocentric mindset, as the picture in Figure 1 represents.

FIGURE 1 - Egocentric and ecocentric mindsets

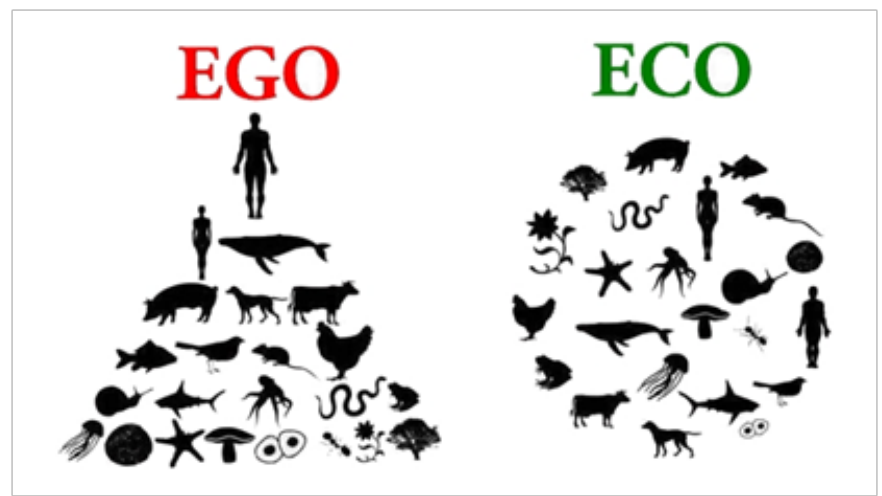

Fonte: Available at: https://serc.berkeley.edu/environmental-ethics-doesyour-ego-get-in-the-way-of-the-eco/. Access on: nov 20, 2020.

The egocentric paradigm places human species above all others in a position of contempt for others. The ecocentric paradigm, instead, places humankind in symmetric intra and interspecies relations, for it understands that placing one group above all else threatens the survival of the whole system. The term joins ecology with the acknowledgement that there is an interdependence relation among human beings and also among human and non-human beings, and that each component of the Earth is inseparable 
with intrinsic value regardless its monetary worth for human use. It understands that we are all connected by interdependent links (BOFF, 2017; SCARANO, 2019; GLEISER, 2014). That's why these scholars advocate that Science in the 21 st century must go along with an ethics of caring - for Nature and for others.

Caring means getting involved (BOFF, 2017; SOUSA SANTOS, 2019), and caring for the space also means taking care of the goods the space offers us: water, seeds, climate, nutrients, forests, flowers, etc. It is indispensable that we rethink the surplus accumulation mindset and fight for an equitable division of work, for anti-racist initiatives, anti-sexist public politics and social justice. I want to suggest, so, that fighting for the environment means also fighting for social justice, and that social justice and environmental justice are inextricably linked.

We are just a tiny, but intelligent, component among a rich variety of living creatures who are supposed to enjoy but also care for the soils, waters and air. That's why Professor Kenneth Worthy believes our way of living has to change either one way or another, as he states: "either we change the capital economy to something that is more congruent with ecology and partnership ethics or the changes in Nature will result in changes to the capital system", Ken Worthy, interviewed by Evans (2019). The change is a commitment not only to our generation but also to the ones to come. I guess it is not a matter of willing or not; it is a matter of survival. I believe we are, actually, living a Darwinistic moment both social and biological. We either evolve or perish. It's worth remembering that evolution is not a passive adaptation of an organism to its environment, once the environment, itself, is a flux, and its elements are being constantly built and re-built by the living organisms in the biosphere. That feels encouraging [or not] once the opportunity to change is in our hands. So, at least for the sake of ourselves we should engage on bringing forth Nature to the role of interlocutor in our discursive space to build a new paradigm.

Based in Vernadsky's (1998) and Teilhard de Chardin's (2002) concepts of noosphere - the highest sphere on Earth constituted by the biosphere plus the human technology, science, speculation, arts, ethics, that is, our rational interference -, recent scientific strings (SCARANO, 2019; OLDFIELD; SHAW, 2016), affirm that humankind constitute the conscious part of the Earth, the thinking living creatures within the whole. According to these scientists, the mental capabilities of humans, together, transform 
the space and have a great geological influence upon the evolution processes on the Earth, as whole. Supported by the Jungian model of collective unconsciousness, these scholars say that humans' social interactions gather, little by little, pieces of consciousness from each individual to construct a collective consciousness for the Earth. That means that we are the part of Nature that holds the ability to modify the Earth, as a discursive space, bringing culture, technology and arts onto it. What these scientists advise is that the same way we, as individuals, should have consciousness and unconsciousness working in harmony to avoid psychopathologies, maybe humanity is sick because our conscious self does not dialogue with the unconscious self.

\section{Toward a new narrative}

As a species, humans are fragile. We don't own ultra-resistant bones, sharp claws, strong teeth, superior body structure, like other mammals; however, even with all these limitations, we are able to interfere in space by building houses, producing fire, sewing clothes, cooking food, inventing cell phones, home computers and spaceships. Moreover, we compose music and poetry, paint pictures, and cultivate spirituality. Major innovations on terrestrial space are anthropogenic: domestications, development of agriculture, and, unfortunately, the high scale extinctions. According to Harari (2018), Ribeiro (2019) and Worthy (2008), among others, the essential reason for the human superiority over other living creatures is the ability to use symbolic language, that bestowed us memory, critique, intention, and let us improve our performance on earth. The ability to create narratives, and, ultimately, to believe in the same narrative and cooperate to follow its principles, is, according to Harari (2018), the most important element for our superiority.

As an example of the extent that linguistic ability and its technologies for dissemination are directly connected to our huge interference in space, I would compare the different evolution processes of the new coronavirus and of the humans. As far as we know, viruses must undergo a series of steps to evolve and stay alive, all of which are one-to-one. The new coronavirus in Italy cannot communicate with other viruses located in other parts of the world to share information or give instructions on how to operate from one state to another, or where to find the best hosts. On the other hand, an 
Italian scientist may communicate their research outcomes to fellows around the world, and new actions can be taken in fighting the virus. Viruses need a one-to-one transmission. Humans, on the contrary, can share produced knowledge in large scale. Information sharing is the great weapon of domination our species truly holds to exist and overcome natural predators. As McNeil (1976) notes,

Language, in short, made hunters fully human for the first time, inaugurating a new dimension of social-cultural evolution which soon put vast and hitherto unmatched strains upon the ecological balance within which humanity arose (McNEIL, 1976, p. 18).

Arendt corroborates the importance of language in our transformation processes as she asserts that discourse can instigate action: "no other human activity needs discourse as much as the action"13 (ARENDT, 2007, p. 192). So, the same way we used the language to evolve from cave hunters to fully humans, we should use language and discourses to incite a new interpretation model to signify the space we live in - as a giant living organism. Mattos (2010, p. 589) stresses the importance of narratives for our constitution as subjects, and infers that "it is through the stories they tell us and the stories we tell, including about ourselves, that we are formed and transformed each day, continuously". ${ }^{14}$ So, day by day, little by little, through repetition, narratives told and believed have the power to direct the course of humanity. Once upon a time in human History, the Europeans created a metanarrative, believed it and engaged all their efforts to doing so: the narrative was that they needed to expand territorial domains. We, Western individuals, believed the liberal narrative, and made the choice of working hard to buy products and enjoy them. In this sense, we can affirm that our strength comes from unity in believing the narratives we were told, and acting in cooperation.

Modernity thought, ingrained in our contemporary practices, has encouraged us, since our childhood, to be competitive, not cooperative

\footnotetext{
${ }^{13}$ In the original: "Nenhuma outra atividade humana precisa tanto do discurso quanto a ação."

${ }^{14}$ In the original: "é por intermédio das histórias que nos contam e das histórias que contamos, inclusive sobre nós mesmos, que nos formamos e nos transformamos a cada dia, continuamente."
} 
(BAUMAN, 2017) within the spaces we occupy. That appears to be counterproductive, since we, as a species, know that cooperation was the element that made us stronger. To form a community, it is not enough to have a group of individuals - it is necessary to develop and solidify pacts of affection, understanding, respect and solidarity. That's why the individualistic narrative demands an urgent review and replacement for another one collectively built and based on cooperation, solidarity, respect and dialogue - not only with humans, but bringing all living creatures to the dialogue.

The North American writer Jonathan Safran Foer (2020) advises that the planetary crisis does not compose a "good narrative", an attractive plot that holds the reader or makes people feel engaged with, because it is shown as an apocalyptical event - something to happen in the future. I consider his assumption as a very important issue to focus on as language teachers and teacher educators. According to Foer, although the climate change is dramatic, people do not engage because it is presented as something that will only happen in the future. As teachers and educators, we should show the real face of it: slow, keen but subtle, eclectic and with no iconic moments or characters. But as the writer instructs, it has to be done "in a way that is both true and engaging." 15

In his words,

\begin{abstract}
Although the planetary crisis has to do with all of us, it looks a lot like a war going on far away. We are aware of its existential risks and its urgency, but even though we know that a war is going on for our survival, we do not feel immersed in it. This gap between awareness and sensation can make it difficult for even thoughtful and politically engaged people - people who want to act - to take action ${ }^{16}$ (FOER, 2020, p. 21).
\end{abstract}

The author calls our attention to the fact that natural problems are the main threat to human existence on Earth but it is curiously called

\footnotetext{
${ }^{15}$ In the original: "De forma que seja tanto verdadeira quanto envolvente."

${ }^{16}$ In the original: "Embora a crise planetária tenha a ver com todos nós, ela se parece muito com uma guerra acontecendo lá longe. Temos consciência de seus riscos existenciais e sua urgência, mas, mesmo sabendo que está acontecendo uma guerra por nossa sobrevivência, não nos sentimos imersos nela. Essa distância entre consciência e sensação pode dificultar que até mesmo pessoas ponderadas e engajadas politicamente - pessoas que querem agir - tomem uma atitude."
} 
"environment crisis" instead of "human crisis". He says that sustainability happened to be something reduced to knowing how to discharge residuals, planting trees, almost like a burden to the common citizen. However, sustainability is achievable if we fight the right battles. The threat is concrete, not conceptual. And we, as a species, are the ones to blame.

Worthy (2008) coined the concept of "phenomenal dissociation" to express a lack of immediate engagement with the consequences of our daily actions. The author, thus, exemplifies the operation of phenomenal dissociation:

Cutting down a tree by myself with an ax, I am immediately and sensually aware of the process and the nonhuman other(s) affected by my labor. When I buy, use, and dispose of paper, I also have material relationships with some trees, but because I have no phenomenal engagement with those trees, my relationships with them are phenomenally dissociated ones (p. 149).

Having abstract, conceptual knowledge of the problem does not imply effectively action to transform a disturbing situation, a problematic issue. We simply ignore what happens because we do not associate ourselves with the phenomenon, and keep on depriving other living creatures with our everyday choices. That means that being disconnected from environmental issues can generate a global ignorance upon how our own lives depend on others and how intricate is the net we are part of. This global ignorance is also perverse because it makes us vulnerable to accept the blame as ordinary citizens for the entire climatic catastrophe without realizing that, in fact, we are immersed in an extractive capitalist structure that should be completely changed to make way for a re-humanization project of society (COMPARATO, 2006).

Worthy advocates that "phenomenal dissociations increase destructive tendency, and, because phenomenal dissociations proliferate in modern life, they play a critical role in the proliferation of environmental degradation" (WORTHY, 2008, p. 150). The Earth Charter Initiative, a document that offers guidelines for using the Earth Charter document in Education, claims that social, economic and environmental concerns are interdependent and interconnected, which means saying that caring for social justice has direct 
impacts on ecological integrity, and has also impacts on living community (p. 4). ${ }^{17}$

In the same direction, some psychologists and physicians have recently defended that a good relationship with the environment may be a key action for better body, mental and social health (WORTHY, 2008). Furthermore, some psychiatrists agree that the space we live in is so determinative for the good or the bad impact in our lives, that they have been experimenting medical treatments for depression and traumas by focusing the cure on a dynamic modification of the space (plants, fresh air, pure water, pleasant companionship) rather than on medicine prescription (RIBEIRO, 2019). In Canada, the outcomes of a research project conducted by the Forest and Nature school program, indicate that outdoor education practice for children "has the potential to significantly increase physical activity levels of individuals resulting in improved quality of life, decreased absenteeism, increased productivity rates, and decreased strain on the Health Care system". ${ }^{18}$ Also, The 2020 Human Development Report emphasizes that "planetary and social imbalances reinforce each another" (UNDP, 2020, p. 3). All those research results and experiments underpin my argument that we should bring planetary issues to language classrooms if we are to fight for a more just society.

Language is frequently manipulated to perpetuate the dichotomy man-woman, male-female, master-servant, mind-body, human-nature, natural-social. Such dichotomies promote separation, and generate abyssal lines (SOUSA SANTOS, 2019). So, maybe, it is time to bring forth the environmental issues to critical linguistic education, blur the frontiers and fuzz the abyssal lines we have built with our European anthropocentric discourses and narratives. Maybe we will finally understand that we are all, indeed, part of a whole, and, this way, naturalize the idea of a plural society in which belonging is not a privilege for few.

I suggest that the link between phenomenal dissociation and destructive discourses and actions in society should be a concern in the field of Applied Linguistics. Although most of us are aware, at least in part, of the harm modern industrial capitalist ways of life provoke to the environment,

\footnotetext{
${ }^{17}$ Available at: https://www.academia.edu/4479110/A_Guide_for_Using_the_Earth_ Charter_in_Education?email_work_card=view-paper. Accessed on: Jan. 16, 2021.

${ }^{18}$ Available at: https://www.outdoorcouncil.ca/About-Us. Accessed on: Jan. 17, 2021.
} 
this knowledge does not prevent destructive actions nor does it push us to re-examine our daily choices because abstract, theoretical environmental education won't do; it has to be a sensitive one, a body-based one, to let students feel, rescue body sensations, develop engagement, in order to understand and dialogue with Natural entities. According to Worthy (2008), social structures are effective to phenomenally dissociate people and to promote alienation of responsibility. According to the author, a consequence of phenomenal dissociation in our practical lives is that we consume goods regardless of their costs to peoples or to the environment. On the other hand, if we get engaged with Nature and human beings, keep attentive to human lives worth and consider the subjectivity of natural entities such as mountains, rivers, trees and other animals besides us, we may undertake the effort to switch the abyssal mindset for an inclusive one.

It is urgent to construct a new, attractive narrative for us to believe and belong. As Maturana (2004, p. 109) observes, "collaborating and sharing implies participating in a common project with others, which is only possible if, in coexistence with others, they can be seen and heard, be respected and respect". ${ }^{19}$ That means, if we do not understand the actual immediate, oncoming and long-term consequences of our daily choices as individuals and as a society, if we don't believe in a common narrative, we will not engage in the common project of saving ourselves from extinction. The phenomenal dissociation will keep crossing our identities, our life styles and, consequently, our daily attitudes.

Therefore, as linguistic educators I suggest we should dedicate some amount of attention to the role narratives have been playing on stealing from us the necessary new life pattern: one that acknowledges that we all have ecological responsibility. This is why I want to borrow Krenak's (2020) assertion mentioned in the introduction of this essay - life is implicated with other lives - to advocate in favor of a literacy pedagogy that I call implicated literacies, that is, literacy pedagogies that include and welcome environmental concerns; that underpin the pedagogical proposals with the acknowledgement that life on Earth begets life; that considers the Earth as a giant living organism, a natural discursive space with natural entities which

\footnotetext{
${ }^{19}$ In the original: "colaborar e compartilhar implica em participar com os outros de um projeto comum, o que só é possível se, na convivência com o outro, possa ser visto e escutado, ser respeitado e respeitar."
} 
are not simple resources for humans; and that take very much into account the close relationship between environmental and social problems.

I feel it is urgent to welcome Scarano's suggestion of having "a living planet in which particles, letters and ideas converge and diverge giving rise to new forms, new states of being, new thoughts" ${ }^{20}$ (SCARANO, 2019 , p. 65). The human-nature alienation narrative is fomenting a global proliferation of environmental destruction and has been killing us all little by little. It is time to bring this issue into language classes, as to remember that power is a collective outcome, and that we cannot think of our life as if it were only ours, once we are collective subjects (KRENAK, 2020) and the individualistic discourse is nothing but a fake narrative.

\section{Implicated Literacies - life implicating life}

As we have been discussing, some contemporary researchers understand Nature's issues as part of the social problems on the space we live in (MATURANA, 2004; NICOLESCU, 1999; SCARANO, 2019; SOUSA SANTOS, 2019). For them, sustainability is a concept related to values, science, politics and utopia (SCARANO, 2019) and not restricted to the environment. They also agree that environmental matters cross questions of race, sex, gender, human rights, nationalisms, citizenship, governance, sovereignty among others. So, they advocate in favor of rescuing the several knowledges once erased by the abyssal line, to discuss our global responsibility towards our partners and our space, and our collective role as human interlocutors of the Natural entities on Earth. So, it's time to listen to aboriginal leaders, indigenous communities, country people and scientists to enlarge our limited views.

The famous Chief Seattle Letter to All, whose speech is believed to have been given in December, 1854, as an answer to President Washington Pierce, who wanted to buy the Suquamish ${ }^{21}$ lands, may inspire us to think the Natural entities as active interlocutors:

\footnotetext{
${ }^{20}$ In the original: "um planeta vivo no qual partículas, letras e ideias convergem e divergem dando origem a novas formas, novos estados de ser, novos pensamentos."

${ }^{21}$ Suquamish is one of many Indian Tribes that inhabit the USA.
} 
Each glossy reflection in the clear waters of the lakes tells of events and memories in the life of my people. The water's murmur is the voice of my father's father. The rivers are our brothers. They quench our thirst. They carry our canoes and feed our children. So, you must give the rivers the kindness that you would give any brother [...] the air shares its spirit with all the life that it supports. The wind that gave our grandfather his first breath also received his last sigh. The wind also gives our children the spirit of life. [...] What befalls the earth befalls all the sons of the earth. This we know: the earth does not belong to man, man belongs to the earth. All things are connected like the blood that unites us all. Man did not weave the web of life, he is merely a strand in it. Whatever he does to the web, he does to himself. ${ }^{22}$

When I argue in favor of implicated literacies for critical linguistic education, I don't mean including disciplinary subjects of Nature or inserting environmental questions as a climate crisis bonus for class, but understanding that "man belongs to the earth" and that Nature relations are part of the social interactions, and social relations constitute a part of sustainability as well, as Maturana (2004) indicates. I aim at approximating the dialogue between ecological studies and linguistic studies. Thus, I mean a language education that thinks literacies for negotiating meanings not only with our fellow humans but also with our environment co-builders. Therefore, it becomes important to reflect upon what kind of discursive spaces occupation we are preparing our students for - a cooperative or an individualistic one - and to encourage the students to acknowledge the irresponsible interferences of humans upon the Earth so that they comprehend that a sustainable way of life should become a collective value and not a deviant behavior of some activists, as it has been these days. If we do not bring this issue into the classroom, the climate problem will keep on being a problem in so far away.

Implicated literacies imply recognizing that the natural entities are potential interlocutors whom we should learn how to listen to, and with whom we should negotiate meanings (REZENDE; TSORORAWE, 2020). The objective is "to know with not to know about" nature (SOUSA SANTOS,

${ }^{22}$ Available at: http://www.csun.edu/ vcpsy00h/seattle.htm. Accessed on: Jan. 15, 2021. 
2019, p. 234). But, learning to negotiate meanings with the living creatures of the Earth demands an "ethical reconstruction program for the world" (COMPARATO, 2006, p. 407).

One may find it strange that the Applied Linguistics field becomes concerned with environmental issues, so distant these topics are considered to be from the language field. Nevertheless, this separation prevents us from seeing humans in our wholeness as biosocial creatures, namely, a part of nature: besides being social subjects, humans are also animals. Besides, once environmental issues are, indeed, linked to the responsible administration of material wealth, we may affirm that they are connected to social problems and to discursive questions. Capitalism needs materialistic, individualistic, competitive and cumulative individuals; but the Earth, in its turn, demands implicated individuals, who are willing to engage in a caring ethics. Thus, I would like to propose a linguistic education with implicated teachers, developing implicated literacies focused on ideas of cooperation, reciprocity, sympathy and mutuality.

\section{Current Initiatives for a new educational proposal}

Lankshear and Knobel (2018) have long proposed that the educational ideal should include the dimension of learning to become stewards of the Universe, in an extent that we should identify and recognize our place in the Universe "within the larger order of things" (p. 10). That means to me that we must develop education designs that privilege our knowledge of who we are and in what ways we can interfere within this larger order. Some educational institutions have been focusing on that, and I'd like to spend some lines to approach their work.

One initiative is the Student Environmental Resource Center, a department at the University of California, Berkeley, that was envisioned in 2012 by UC Berkeley students, who determined the need for a campus center for the student environmental and sustainability community. They actively work to disseminate new values for a new mindset. They are mostly interested in conscious impact, equity and inclusion, community engagement, student sovereignty, bold imagination. ${ }^{23}$ Their focus sits

\footnotetext{
${ }^{23}$ Available at: https:/ / serc.berkeley.edu/ environmental-ethics-does-your-ego-get-in-theway-of-the-eco/. Accessed on: Jan. 17, 2021.
} 
on getting out of the egocentric mindset, which regulates on prosperity regardless of the cost for other living creatures into the ecocentric mindset, which considers humans as important for the ecosystem as plants, other animals and land.

Other initiatives are the International Association of Nature Pedagogy, in Scotland, "designed to promote and support all forms of nature-based education for children aged 0-8 years throughout the world", 24 or the Institute Living Trees, in Brazil. ${ }^{25}$ Both initiatives gather forces to develop an environmental culture with a positive relationship with nature and all its elements, with formal and non-formal educational projects.

The Forest and Nature school Programs are movements in countries like Canada, England and Norway that aim at the child's immersion into the natural world. They understand that schools should be outdoors and in contact with Nature. ${ }^{26}$ So, their pedagogies include activities such as observing the sun, the moon and stars, clouds, or caring of a living animal, so that children build their sense of belonging in the world connected with Nature.

In Canada, The Child and Nature Alliance of Canada ${ }^{27}$ states their main interest is to "connect children and youth with nature through policy, research, and practice" and maintain the Forest Schools in Canada as their flagship educational project. Those schools also use aboriginal pedagogy in their classrooms showing the students that their activity has an aboriginal root. That helps create a sense of respect from non-aboriginal children as well as a sense of pride in aboriginal children, who can see their ancestor knowledges being valued.

\section{Conclusion}

After this study, a lesson that remains to me is that the social space we live in includes not only humans and technologies, sciences, politics, arts, we

\footnotetext{
${ }^{24}$ Available at: https://www.naturepedagogy.com/. Accessed on: Jan. 17, 2021.

${ }^{25}$ Available at: https://arvoresvivas.org/. Accessed on: Jan. 17, 2021.

${ }^{26}$ Available at: https://childnature.ca/about-forest-and-nature-school/. Accessed on: Jan. 17, 2021.

${ }^{27}$ Available at: https://childnature.ca/. Accessed on: Jan. 17, 2021.
} 
have hitherto developed, but also rivers, seas, air, fire and the soil we step on, and from which comes the food and everything else we have. Besides, that the space belongs to, is built by, and involves every living creature on this Earth. That means that phenomena happening in China's social collective space may have consequences in Brazil. If there is any harm to the climate in the Northern hemisphere, it ends up altering rainfall, humidity and heat in the Southern hemisphere, which will, consequently, change the proliferation of microorganisms, the soil, its nutrients and handling, and, ultimately, food, flowers, insects, economy, social interactions. Hence, I conclude that environmental and economic issues are part of the same web, as well as cultures and subjectivities.

I tend to think that, once we comprehend that the environment ought to be a shared responsibility, the competitive pattern of education also has to switch to a supportive one. We are at a historical moment when we have reached extraordinary technological improvements, we've detained accumulated knowledges, and can undertake the most varied scientific experiments that enable us to change the course of the world. It is not demanded that we turn back to primitive times in order to have a more sustainable society. We can make use of all this symbolic capital we have conquered to work for an equitable, fairest society in which well-being is a rule.

I hope this study may inspire teachers, researchers and curriculum designers to rethink what has hitherto been done in pedagogical approaches to think of new language teaching practices. Perhaps we may inquire whether we have been stressing the narratives that draw our students away from the relationship with Nature when we ignore these issues in our classes and delegate them to the Natural Sciences teachers.

Moreover, I wish this study may effectively contribute for blurring dichotomic borders and promoting collective responsibility awareness as to create a mindset that eliminates the abyssal lines Western capitalist ideologies insist on building. Our problem, as a species, is not an unsolvable one - an asteroid, or some natural phenomenon beyond our capacities. On the contrary, it is entirely in our power to cooperate, build a new narrative for us to believe, and reset our role within this web we are part of. It is just a matter of choice and engagement. Finally, I strongly desire that further empirical research may be developed to investigate the relationship between 
environmental culture and constructive social behaviors, and new initiatives emerge so that we may, little by little, develop an affection for the Earth, not only a civil obligation. Maybe, knowing will help loving; and loving will push to knowing further.

\section{References}

ARENDT, H. A condição bumana. Trad. Roberto Raposo. 10. ed. Rio de Janeiro: Forense, 2007.

BAUMAN, Z. Retrotopia. Trad.: Renato Aguiar. Rio de Janeiro: Zahar, 2017.

BOFF, L. Ética e espiritualidade: como cuidar da casa comum. Petrópolis, RJ: Vozes, 2017.

BOURDIEU, P. A economia das trocas simbólicas. 8. ed. São Paulo: Perspectiva, 2015.

COMPARATO, F. K. Ética: direito, moral e religião no mundo moderno. São Paulo: Companhia das Letras, 2006.

CHIEF SEATTLE LETTER TO ALL. [s.d.]. Available at: http://www.csun. edu/ vcpsy00h/seattle.htm. Accessed on: Jan 17, 2021.

EVANS, Nicole. Environmental Ethics: Does Your Ego Get in the Way of the Eco? SERC - Student Environmental Resource Center, University of California Berkeley, 2019. Website. Available at: https:// serc.berkeley.edu/environmental-ethics-doesyour-ego-get-in-the-way-of-the-eco/. Accessed on: Jan. 13, 2021.

FOER, J. S. Nós somos o clima: salvar o planeta começa no café da manhã. Trad. Maíra Mendes Galvão. Rio de Janeiro: Rocco, 2020.

GLEISER, M. A Ilha do Conhecimento: os limites da ciência e a busca por sentido. Rio de Janeiro: Record, 2014.

GLEISER, M. O caldeirão azul: o universo, o homem e seu espírito. 6. ed. Rio de Janeiro: Record, 2020.

HARARI, Y. N. 21 liçõespara o século 21. São Paulo: Companhia das Letras, 2018.

KRENAK, A. Papo Astral com Marcelo Gleiser. 2020. Available at: https://www. youtube.com/watch?v=Et7ft9Oz9Cc\&t=994s. Accessed on: Out 30, 2020.

LANKSHEAR, C.; KNOBEL, M. Education and 'New Literacies' in the Middle Years. Literacy Learning: Middle Years, Sydney, Austrália, v. 26, n. 2, p. 7-16, June 2018. Available at: https://www.academia.edu/36969702/Education_and_new_ literacies_in_the_middle_years. Accessed on: Jan 10, 2021. 
MATTOOS, A. M. A. Narrativas, identidades e ação política na pós-modernidade. Revista Educação e Sociedade, Campinas, v. 31, n. 111. p. 287-602, abr.-jun., 2010. DOI: https://doi.org/10.1590/S0101-73302010000200015. Available at: https://www. scielo.br/scielo.php?script $=$ sci_arttext\&pid $=$ S0101-73302010000200015\&lng $=p$ t\&nrm=iso\&tlng=pt. Accessed on: Jan, 19, 2021.

MATURANA, H. Ética e desenvolvimento sustentável: caminhos para a construção de uma nova sociedade. Revista Psicologia \& Sociedade, Porto Alegre, v. 16, n. 2, p. 102110; set./dez. 2004. DOI: https://doi.org/10.1590/S0102-71822004000300013 McNEIL, W. H. Plagues and Peoples. New York: Anchor Press, 1976.

NICOLESCU, B. O manifesto da Transdisciplinaridade. Trad. Lúcia Pereira de Souza. São Paulo: Triom, 1999.

OLDFIELD, J. D.; SHAW, D. J. B. The Development of Russian Environmental Thought. Scientific and Geographical Perspectives on the Natural Environment. New York; London: Routledge, 2016. DOI: https://doi.org/10.4324/9781315670171

OLDSTONE, Michael B A. Viruses, Plagues and History. New York: OUP, 1998.

REZENDE, T.; TSORORAWE, J. Gênero correspondência: recados da natureza na comunicação com seres não-escutados. Abatirá - Revista de Ciências Humanas e Linguagens, Eunápólis, BA, v. 1, n. 2, p. 268-290, jul.-dez., 2020.

RIBEIRO, S. Oráculo da noite. São Paulo: Companhia das Letras, 2019.

SAGAN, Carl. Pálido ponto az̧ul: uma visão do futuro da humanidade no espaço. São Paulo: Companhia das Letras, 1996.

SCARANO, F. R. Regenerantes de Gaia. Rio de Janeiro: Dantes, 2019.

SOUSA SANTOS, B. O fim do império cognitivo: a afirmação das epistemologias do Sul. 1. reimp. Belo Horizonte: Autêntica, 2019.

TEILHARD de CHARDIN, P. The Phenomenon of Man. London: Perennial, 2002.

UNDP. The 2020 Human Development Report: The Next Frontier: Human Development and the Antropocene. New York: United Nations, 2020.

VERNADSKY, V. I. The Biosphere. New York: Copernicus, 1998. DOI: https:/ / doi.org/10.1007/978-1-4612-1750-3

VIVEIROS DE CASTRO, E. Metafísicas Canibais: elementos para uma antropologia pós-estrutural. São Paulo: Ubu, 2018.

WOHLlEBEN, P. A vida secreta das árvores. Trad. Petê Rissati. Rio de Janeiro: Sextante, 2017. 
WOODWARD, A. The End of Time. Pahrresia: A Journal of Critical Philosophy, Melbourne, Australia, n. 15, p. 87-105, 2012. Available at: https://www. parrhesiajournal.org/parrhesia15/parrhesia15_woodward.pdf. Accessed on: Jan. 12, 2021.

WORTHY, K. Modern Institutions, Phenomenal Dissociations, and Destructiveness Toward Humans and the Environment. Organization and Environment, [S.l.], v. 21, n. 2, p. 148-170, June 2008. DOI: https://doi.org/10.1177/1086026608318987. Available at: www.jstor.org/stable/26162328. Accessed on: Jan 12, 2021.

Data de submissão: 19/1/2021. Data de aprovação: 15/2/2021. 